\title{
THE EFFECT OF DEMOGRAPHIC, SOCIAL, AND ECONOMIC CHARACTERISTICS ON CONSUMER EMPOWERMENT IN EDUCATION INSTITUTIONS
}

\author{
Megawati Simanjuntak \\ Department of Family and Consumer Sciences, \\ Faculty of Human Ecology, IPB University, Indonesia \\ E-mail:mega_juntak@apps.ipb.ac.id
}

Siti Umiyati

Department of Family and Consumer Sciences, Faculty of Human Ecology, IPB University, Indonesia

Email: sitiumiyati08@gmail.com

Submission: 9/7/2020

Accept: 9/29/2020

\section{ABSTRACT}

Nowadays, consumers are faced with many options for formal educational institutions. To choose the best institution, consumers need to be well educated and well informed. This research aimed to analyze the influence of demographic, social, and economic characteristics toward formal educational institution consumer empowerment. This research used a cross-sectional study of 52 respondents. The data were analyzed using descriptive and inferential analysis. The consumer's empowerment index in this research was 54.34, which was included in the capable category. The result showed that early adult (19-24 years) females who were highly educated and were not having a job with $\leq \mathrm{Rp} 3,204,551$ income per month were the most empowered group of respondents than others. Regression analysis revealed that age influenced the consumer empowerment index. T-test analysis of the consumer empowerment based on characteristics is not significantly different.

Keywords: Consumer; empowerment; formal; educational; institution; sociodemographic 
DOI: 10.14807/ijmp.v12i5.1443

\section{INTRODUCTION}

Educational institutions are important because, in today's era of globalization and technological advances, the high level of education will be a benchmark for one's success. As a result, everyone is competing to get the best education to achieve prestige and increase the standard of living. A formal education institution is a structured and tiered service provider institution consisting of primary education, secondary education, and higher education (Act of the Republic of Indonesia No. 20 of 2003 on the National Education System).

The management of educational services, both by the government and the private sector, has its characteristics compared to the management of other services, "because in the management of education services there is a load of certain idealistic values” (Sudaryatmo, 1996). Unlike buying and selling transactions in general, where educational institutions provide educational services or products and students pay to get them, the values contained in educational services make the legal aspects of consumer protection appear biased. As if educational services and products are not included in the legal domain of consumer protection, but are the responsibility of the state and solely regarding the rights of citizens, as guaranteed in the 1945 Constitution and related laws and regulations.

Consumer protection efforts are considered successful when Indonesian consumers are empowered, in the sense that consumers understand their rights and obligations and are able to protect themselves from potential losses (Act of the Republic of Indonesia No. 8 of 1999 on the Consumer Protection). The main factor that causes frequent exploitation of consumers is the low level of consumer awareness of their rights (Ishak \& Zabil, 2012). This is evidenced by the low number of the Indonesian Consumer Empowerment Index (CEI) as measured by the Indonesian Consumers Foundation in 2017, around a score of 32 of the total value of 100 (Abadi, 2018) and the results of a survey conducted in 22 provinces show that the CEI value is still low (31.05) where the average in urban areas (33.4) is higher than in rural areas (28.15) (Simanjuntak \& Yuliati, 2016).

According to Ngai et al. (2007), demographic factors play a very important role in consumer complaint behavior. According to Simanjuntak et al. (2013), socioeconomic characteristics have a direct or indirect effect on consumer empowerment. Education level affects consumer empowerment (Rahman \& Naoroze, 2007; Hunter, Harrison \& Waite, 2006; Simanjuntak, 2014). More intensive consumer education can indirectly increase consumer empowerment (Simanjuntak et al., 2013). Job-status also affects consumer empowerment 
DOI: 10.14807/ijmp.v12i5.1443

(Gholipour et al., 2010). Income levels also influence consumer complaint behavior (Handoyo \& Setiawan, 2015).

Various efforts to empower and protect consumers have been made by the government and various non-governmental consumer protection organizations. However, the CEI value in Indonesia is still low. The main problem of consumers in Indonesia is the lack of public awareness of the rights and responsibilities of consumers (Sumiyati \& Fatmasari, 2006). The results of the mapping of the Indonesian CEI conducted by the Indonesian Consumers Foundation (YLKI) show that the value of the Indonesian CEI in 2017 is around a score of 32 from a maximum value of 100 . This value is still much lower than the value of the CEI calculation in developed countries that have already reached more than 50 (Abadi, 2018).

The violations of consumer rights that occur in Indonesia are caused by a number of factors. Among these are the factors in the attitude of business actors who still view consumers as parties that are easily exploited, which is exacerbated by the general public's lack of understanding as to their rights. Many consumers do not know this yet. One of the facts that Indonesian consumers have not been able to fight for their rights can be seen from the behavior of consumers in complaining when a problem occurs.

Based on the complaint data report obtained by the National Commission on Human Rights from 2014 to 2016, it is known that educational institutions are among the top 10 parties complained by consumers. There are problems that are often complained of by consumers of educational institutions, including educational services, cost of education (OSE, 2012), school facilities and infrastructure, and teacher performance. Complaint data reports obtained from the National Commission on Human Rights from 2014 to 2016 are presented in Table 1.

Table 1: Report on consumer complaint data for 2014-2016

\begin{tabular}{|c|c|c|c|c|}
\hline No & Complaints & 2014 & 2015 & 2016 \\
\hline 1 & Police & 2483 & 2734 & 2290 \\
\hline 2 & Corporation & 1127 & 1231 & 1030 \\
\hline 3 & Regional government & 771 & 1011 & 931 \\
\hline 4 & Judicial Institution & 641 & 640 & 436 \\
\hline 5 & Government (Ministry) & 499 & 548 & 619 \\
\hline 6 & BUMN/BUMD & 463 & 381 & 359 \\
\hline 7 & State Institutions (Non-Ministry) & 282 & 288 & 122 \\
\hline 8 & Soldier & 215 & 331 & 280 \\
\hline 9 & Attorney & 195 & 252 & 214 \\
\hline 10 & Educational institutions & 134 & 146 & 108 \\
\hline 11 & Organization & 58 & 55 & 43 \\
\hline 12 & Penitentiary and / or detention center & 44 & 43 & 56 \\
\hline 13 & Health Service Institution & 41 & 44 & 28 \\
\hline 14 & Government of Other Countries & 13 & 9 & 15 \\
\hline 15 & Legislative Body & 1 & 4 & 4 \\
\hline \multicolumn{2}{|c|}{ Total Number of Complaints } & 7285 & 8249 & 7188 \\
\hline
\end{tabular}


DOI: 10.14807/ijmp.v12i5.1443

Source: National Commission on Human Rights Complaint Service Administration Division (2014-2016)

Based on the conditions previously stated, researchers are interested in assessing the level of consumer empowerment, considering that research in the field of consumer empowerment is still limited and not widely done. The measurement of consumer empowerment index in generation Y has yielded 53.84 of the index (Simanjuntak, 2015). Then, in previous studies, consumer empowerment on food sector showed the CEI value of 38.63 (Simanjuntak et al., 2014; Simanjuntak, 2018), the CEI value in urban areas of 28.6 and in rural areas of 41.9 (Simanjuntak \& Mubarokah, 2021), the CEI value of 47.0 in the health insurance sector (Sofyan, 2017), the CEI value of 40.24 in the housing sector (Damayanti, 2017), the CEI value of 49.7 in online purchases (Simanjuntak, 2019; Simanjuntak \& Musyifah, 2016), the CEI value of 44.56 in the field of public transportation (Saniyya, 2017), the CEI value of 41.78 in the field of electronic products (Simanjuntak \& Putri, 2018), the CEI value of 48.85 in the field of health (Simanjuntak \& Yuja, 2021), and the CEI value of 51.685 in the field of telecommunications (Simanjuntak \& Putri, 2020).

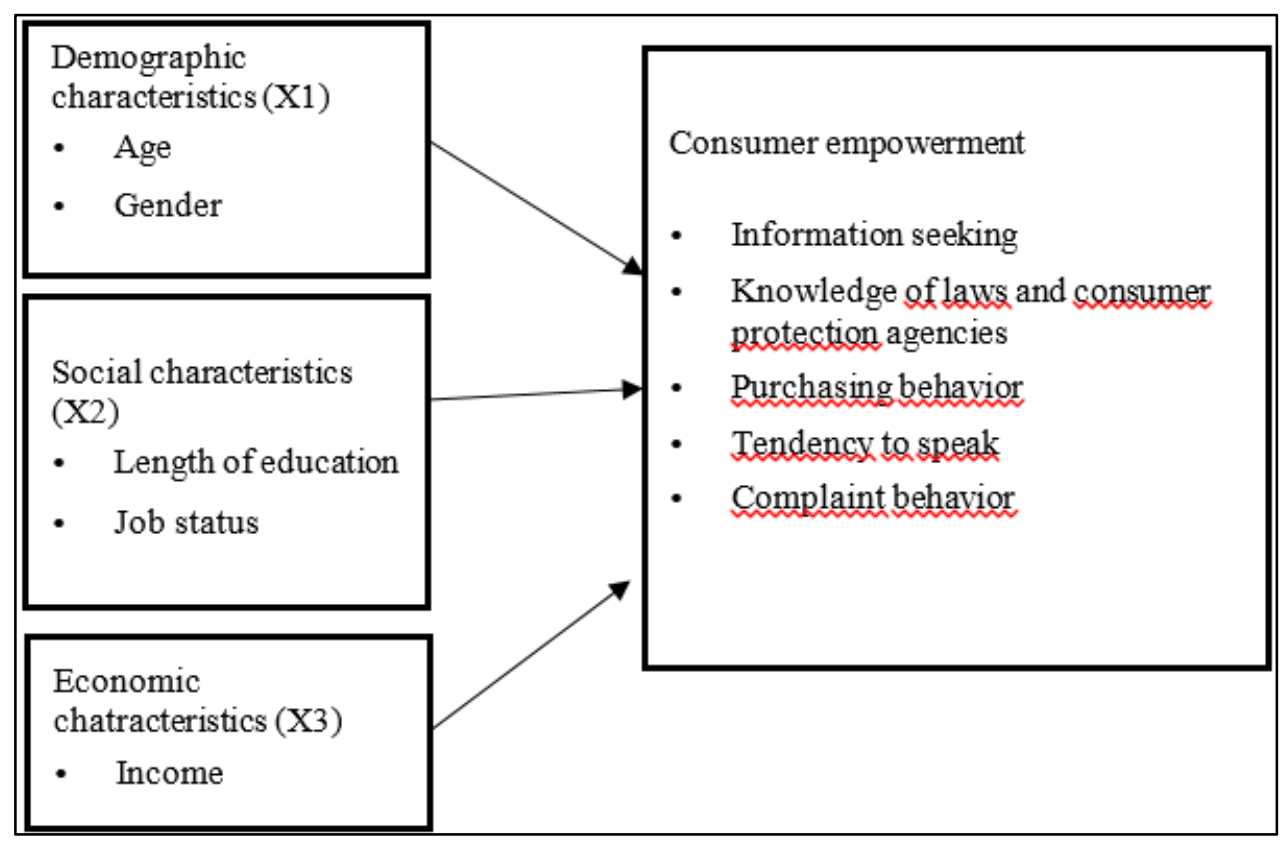

Figure 1: A research framework 
DOI: 10.14807/ijmp.v12i5.1443

\section{LITERATURE REVIEW}

\subsection{Relationship between Demographic Characteristics and Consumer Empowerment}

According to Simanjuntak (2014), the total direct and indirect effect of demographic characteristics significantly affects consumer empowerment. According to NGAI et al. (2007), demographic factors play a very important role in consumer complaint behavior. Gender affects consumer complaint behavior (Heung \& Lam, 2003). Age is proven to have a significant relationship with consumer complaint behavior. Early adults (18-40 years) and middle adults (41-59 years) are more empowered than the elderly ( $\geq 60$ years) group (Simanjuntak, 2014). Age (Damayanti, 2017; Sofyan, 2017) and gender (Simanjuntak, 2019) have a significant effect on consumer empowerment. Based on the analysis of previous research, the following hypothesis is formulated:

- H1a: Age has a significant effect on consumer empowerment.

- H1b: Gender has a significant effect on consumer empowerment.

\subsection{Relationship between Social Characteristics and Consumer Empowerment}

The level of education of the head of the family and the wife, both formally and informally, will influence the way and mindset to be able to meet the needs of life with unfavorable socioeconomic conditions. Higher education is a means to achieve a quality life. A person's education level will also affect their values, way of thinking, perspective, and even their perception of a problem (Tuty et al., 2017). A higher level of education will make it easier for a person or society to absorb information and implement it in daily behavior and lifestyle, especially in terms of consuming goods/services.

Education shows the level of intelligence related to one's thinking power. The higher the education of a person, the wider the knowledge. Education is a dimension of consumer empowerment, so it is important to understand and use available information (Cutler \& Nye, 2000; Hunter, Harrison \& Waite, 2006). Killackey-Jones et al. (2004) also showed that educational interventions could significantly improve respondents' knowledge, attitudes, and behavior.

However, according to Burghelea and Aceleanu (2014), the situation of consumers does not solely depend on consumer education, but other factors such as consumer protection institutions, law enforcement, knowledge acquisition through informal means, or different consumer needs. According to research by Sofyan (2017), Simanjuntak and Putri (2020), and 
DOI: 10.14807/ijmp.v12i5.1443

Simanjuntak and Mubarokah (2021), the length of education affects the consumer empowerment index.

Most consumers will seek information in advance regarding the product/service to be used before finally making a purchase decision. The explanation above is in line with the opinion of BPOM Ri (2008), which states that empowered consumers are consumers who have high awareness and knowledge of the quality and usefulness of a product or service. Sofyan (2017) and Saniyya (2017) state that job status affects the consumer empowerment index.

Based on the previous analysis, the following hypothesis was formulated:

- H2a: The level of education has a significant effect on consumer empowerment.

- H2b: Job-status has a significant effect on empowerment.

\subsection{Relationship between Economic Characteristics and Consumer Empowerment}

Consumer empowerment is influenced by income (Simanjuntak, 2014). The results of an empirical study of the factors that influence empowerment are education, resource availability, political support (Spreitzer, 1995), women's work and household participation levels (Chaudhry \& Nosheen, 2009), income (Chandrasekhar, 2012; Gholipour et al., 2010; Chaudry \& Nosheen, 2009; Collard et al., 2006; Tayde \& Chole, 2010; Sofyan, 2017; Simanjuntak, 2019; Damayanti, 2017). So, the hypothesis can be formulated as follows:

- H3: Family income has a significant effect on consumer empowerment.

\section{RESEARCH METHODOLOGY}

This study used a cross-sectional study design. The data collection was conducted through a survey. The sample in this study is the parents or guardians of students studying nonformal high school education institutions. The number of respondents in this study was 52 respondents. The type of data used in this study was the primary data. Primary data were collected through self-administered with a questionnaire tool. The primary data included demographic, social, and economic characteristics, including age, gender, length of education, job status, and income.

Consumer empowerment is measured using the modified instrument of Simanjuntak (2014) and with a 2-point scale: 0 = No/Not correct/Do not know, and 1 = Yes/Correct/Know. Consumers in this study were categorized into five groups, namely: 1) aware (score 0-20), understand (20.1-40), capable (40.1-60), critical (60.1-80), empowered (80.1-100). The dimensions of the consumer empowerment index included information seeking, knowledge of laws and consumer protection agencies, purchasing behavior, tendency to speak, and complaint 
DOI: 10.14807/ijmp.v12i5.1443

behavior. The reliability value of the consumer empowerment instrument ranges from 0.5990.753. The research was conducted to answer the following hypothesis:

- H1a: Age has a significant effect on consumer empowerment

- H1b: Gender has a significant effect on consumer empowerment

- H2a: Length of education has a significant effect on consumer empowerment

- H2b: Job-status has a significant effect on consumer empowerment

- H3: Income has a significant effect on consumer empowerment

\section{RESULT AND DISCUSSION}

\subsection{Respondent Characteristics}

The results showed that 8 out of 10 respondents were in the middle-aged category (3650 years) with an average age of 43.23 years. Most of the respondents were female (75\%), and the rest were male (25\%). Based on the results of the study, the largest percentage of respondents' length of education was 12 years (51.9\%). The average length of education of the respondents was 13.17 years (graduated from high school). Based on the obtained data, the largest percentage of the respondents' job status was employed. The results showed that the average income of the family was Rp4,629,807.69/month, which is considered a high level of income.

\subsection{Consumer Empowerment}

\subsubsection{Information Seeking}

Information seeking is how often the respondent searches for information when choosing an educational institution. The information-seeking dimension was measured by a scale of never, sometimes, often, and always. The results showed that $17.3 \%$ of respondents never sought information about existing facilities in educational institutions. As many as 34.6\% of respondents sometimes seek information about facilities in educational institutions. As many as $32.7 \%$ of respondents often seek information about the curriculum used in educational institutions. As many as $46.2 \%$ always seek information on fees for educational institutions. 
INDEPENDENT JOURNAL OF MANAGEMENT \& PRODUCTION (IJM\&P)

http://www.ijmp.jor.br

v. 12, n. 5, July-August 2021

ISSN: 2236-269X

DOI: 10.14807/ijmp.v12i5.1443

Table 2: Distribution of respondents based on item dimensions seeking information

\begin{tabular}{lccccc}
\hline \multicolumn{1}{c}{ Indicator } & $\begin{array}{c}\text { Never } \\
(\%)\end{array}$ & $\begin{array}{c}\text { Sometimes } \\
(\%)\end{array}$ & $\begin{array}{c}\text { Often } \\
(\%)\end{array}$ & $\begin{array}{c}\text { Always } \\
(\%)\end{array}$ & $\begin{array}{c}\text { Mean } \\
(\text { scale 1-4)* }\end{array}$ \\
\hline Accreditation & 11.5 & 30.8 & 26.9 & 30.8 & 2.77 \\
Facilitation & 17.3 & 34.6 & 25.0 & 23.1 & 2.54 \\
Cost & 3.9 & 21.2 & 28.9 & 46.2 & 3.17 \\
Curriculum & 11.5 & 28.9 & 32.7 & 26.9 & 2.75 \\
\hline
\end{tabular}

Note. * Never (1); Sometimes (2); Often (3); Always (4)

\subsubsection{Knowledge of Laws and Consumer Protection Agencies}

Knowledge about the law and the consumer protection agencies is the extent to which respondents know about the Consumer Protection Act, consumer rights protected by the law, and advocacy rights as consumers. The results showed that as many as $78.9 \%$ of respondents knew about the law. Half of the respondents know their rights as consumers (50\%). Only 48.1\% of respondents know their obligations as consumers. As many as $78.9 \%$ of respondents know the consumer's legal protection rights. Most of the respondents are aware of consumer protection agencies (80.8\%). Most of the respondents are aware of the Consumer Dispute Resolution Agency (BPSK) (90.4\%).

Table 3: Distribution of respondents based on item dimensions of knowledge about the Law and Consumer Protection Institutions

\begin{tabular}{lcc}
\hline \multicolumn{1}{c}{ Indicator } & Know (\%) & Do not Know (\%) \\
\hline Consumer Protection Act & 78.9 & 21.1 \\
Consumer rights & 50.0 & 50.0 \\
Consumer obligations & 48.1 & 51.9 \\
Consumer legal protection rights & 78.9 & 21.1 \\
Consumer protection agencies & 80.8 & 19.2 \\
Consumer Dispute Settlement Agency (BPSK) & 90.4 & 9.6 \\
\hline
\end{tabular}

\subsubsection{Purchasing Behavior}

Purchasing behavior is the extent to which consumers check educational institutions. Based on the results of the study, $17.31 \%$ of respondents never asked about existing facilities in educational institutions. As many as $26.92 \%$ of respondents sometimes asked about the existing facilities in the educational institution to be selected. As many as $26.92 \%$ of respondents often asked about existing facilities at the educational institution that they would choose. As many as 7 out of 10 respondents always pay attention to accreditation before choosing an educational institution. On average (1-4 scale), respondents pay attention to accreditation (3.34) before choosing an educational institution.

Table 4: Distribution of respondents based on the dimensions of purchasing behavior

\begin{tabular}{lccccc}
\hline \multicolumn{1}{c}{ Indicator } & Never (\%) & Sometimes (\%) & Often (\%) & Always (\%) & Mean (scale 1-4)* \\
\hline Allocation Details & 1.9 & 25.0 & 11.5 & 61.5 & 3.33 \\
Accreditation & 3.9 & 17.3 & 9.6 & 69.2 & 3.34 \\
Facility & 17.3 & 26.9 & 26.9 & 28.9 & 2.67 \\
Cost & 0.0 & 13.5 & 21.1 & 65.4 & 3.52 \\
Curriculum & 15.4 & 19.2 & 25.0 & 40.4 & 2.90 \\
\hline
\end{tabular}


DOI: 10.14807/ijmp.v12i5.1443

Note. * Never (1); Sometimes (2); Often (3); Always (4)

\subsubsection{Tendency to Speak}

The tendency to speak is whether the respondent shares good or bad experiences with others in choosing an educational institution. Based on the results of the study, as many as 3.8\% of respondents had never shared good experiences or bad experiences with others. As many as $48.1 \%$ of respondents sometimes shared good experiences with others. As many as $46.2 \%$ of respondents often tell bad experiences to others. As many as $28.1 \%$ of respondents always shared bad experiences with others. On average (scale 1-4), respondents often tell bad experiences to others.

Table 5: Distribution of respondents based on the speaking tendency dimension

\begin{tabular}{cccccc}
\hline Indicator & $\begin{array}{c}\text { Never } \\
(\%)\end{array}$ & $\begin{array}{c}\text { Sometimes } \\
(\%)\end{array}$ & $\begin{array}{c}\text { Often } \\
(\%)\end{array}$ & $\begin{array}{c}\text { Always } \\
(\%)\end{array}$ & $\begin{array}{c}\text { Mean } \\
(\text { scale 1-4)* }\end{array}$ \\
\hline Telling bad experiences to others & 3.8 & 1.9 & 46.2 & 28.1 & 3.38 \\
Telling good experiences to others & 3.8 & 48.1 & 32.7 & 15.4 & 2.60 \\
\hline
\end{tabular}

Note. * Never (1); Sometimes (2); Often (3); Always (4)

\subsubsection{Complaint Behavior}

Complaint behavior is the extent to which consumers file complaints when they find losses or disappointments at educational institutions. Based on the results of the study, 73.1\% were in the poor category of complaining. This indicates the respondents' lack of awareness to complain when they get a loss or disappointment.

Table 6: Distribution of respondents based on the frequency of complaint behavior

\begin{tabular}{ccc}
\hline Frequency of complaints & $\mathrm{n}$ & $\%$ \\
\hline Very low $(<=25)$ & 8 & 15.4 \\
Low $(25.1-50)$ & 38 & 73.1 \\
High (50.1-75) & 6 & 11.5 \\
Very high $(>75)$ & 0 & 0.0 \\
\hline Min-Max & \multicolumn{2}{c}{} \\
Mean & \multicolumn{2}{c}{41.99} \\
\hline
\end{tabular}

The results of the research in Figure 2 show that the Consumer Empowerment Index in educational institutions is 54.34 out of 100 . Based on its dimensions, purchasing behavior has the highest index compared to other dimensions. This means that respondents from educational institutions have fairly good buying behavior. Meanwhile, the dimension with the lowest index is the complaint behavior dimension. This means that respondents are still lacking in defending their rights so that they lack the awareness to make complaints when they are dissatisfied or disappointed with educational institutions. The earlier studies found that complaint behavior also still lacking (Simanjuntak, 2019; Wandani \& Simanjuntak, 2019), thus, it needs more attention (Simanjuntak \& Hamimi, 2019). 
INDEPENDENT JOURNAL OF MANAGEMENT \& PRODUCTION (IJM\&P)

http://www.ijmp.jor.br

v. 12, n. 5, July-August 2021

ISSN: 2236-269X

DOI: 10.14807/ijmp.v12i5.1443

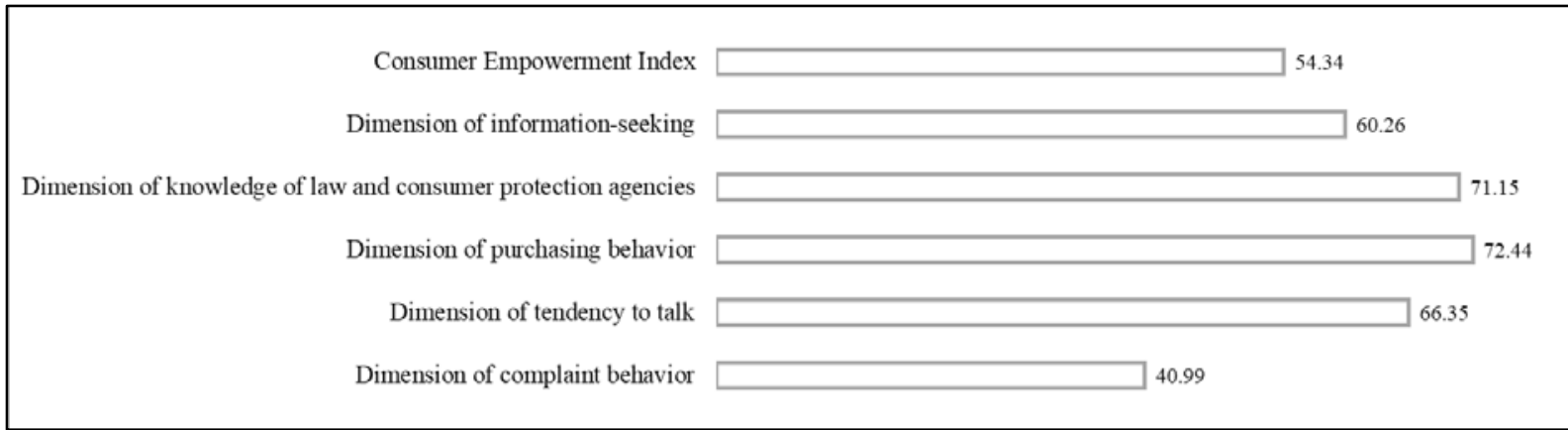

Figure 2: The average value of CEI and its dimensions in educational institutions

Based on Figure 3, the average consumer empowerment index in the category of early adulthood (19-24 years) was higher than that of other age categories. The average index for female consumer empowerment was higher than that of male respondents. Based on the length of education, the index average of $\leq 12$ years of education was higher than that of consumers with $>12$ years of education. Respondents who did not work had a higher consumer empowerment index than respondents who worked. Based on income, respondents whose income was $\leq \mathrm{Rp} 3,204,551$ had a higher average empowerment index than respondents whose income was $>$ Rp3,204,551. In simple terms, it can be concluded that in female educational institutions who were early adulthood (19-24 years), had middle school education ( $\leq 12$ years), did not work, and had an income of $\leq \mathrm{Rp} 3,204,551$ were the most empowered respondents compared to other groups of respondents.

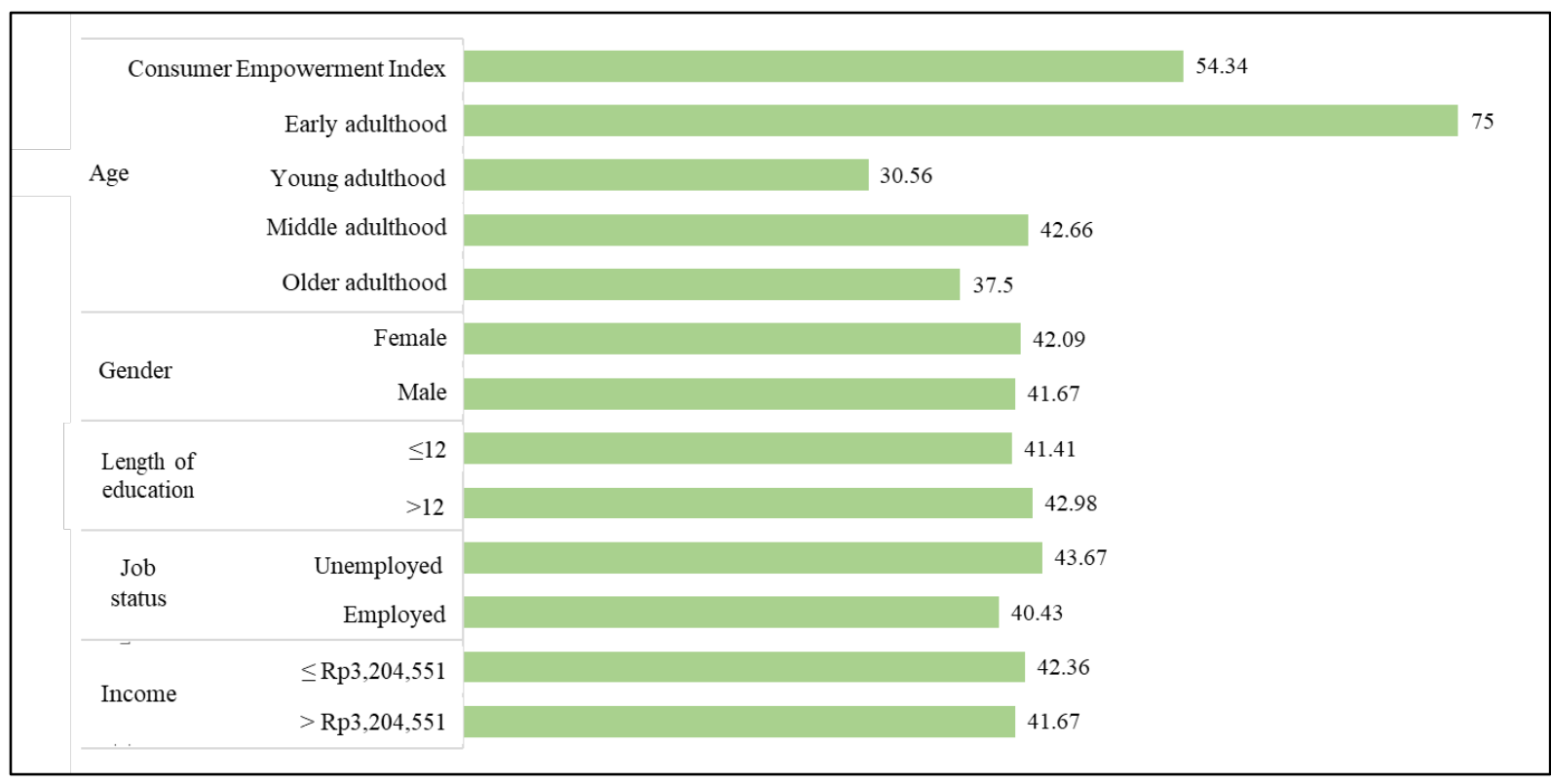

Figure 3: Consumer empowerment index based on respondent characteristics

\subsubsection{Consumer Empowerment Index}

The consumer empowerment index is the subjective condition of consumers who are skilled, know the laws and consumer protection agencies, actively seek information, and 
confirm only by filing a complaint. According to Simanjuntak and Yuliati (2016), the CEI category is aware, understand, capable, critical, and empowered. Based on Figure 4, in educational institutions, respondents reached the capable stage (57.7\%). This means that the majority of respondents have been able to exercise consumer rights and obligations, but have not played an active role in fighting for consumer rights. The highest CEI category achieved was critical (32.7\%).

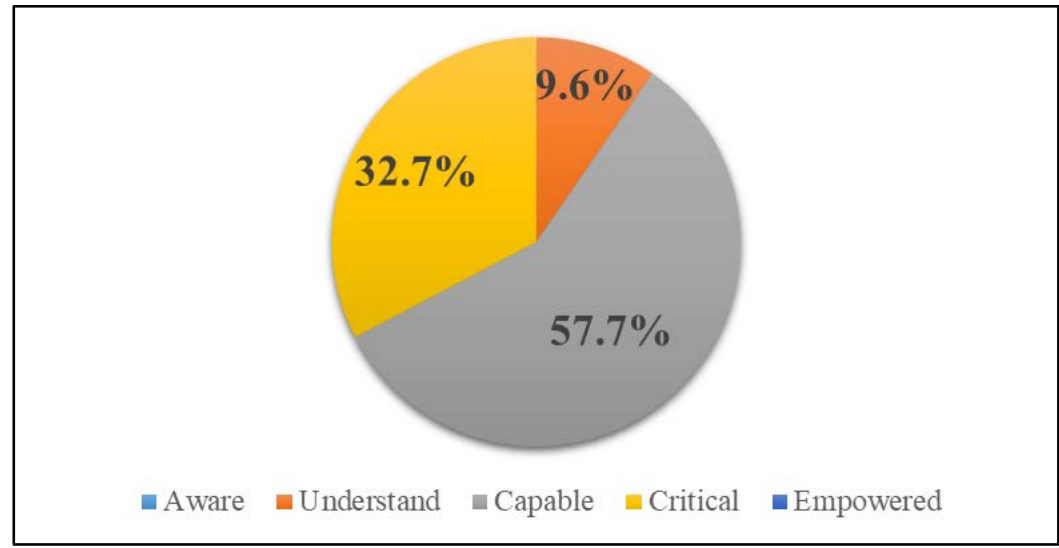

Figure 4: Categories of consumer empowerment index in educational institutions

\subsection{Factors Affecting Consumer Empowerment in Educational Institutions}

The classical assumption test was carried out to fulfill the predetermined requirements before conducting the regression test, including normality, heteroscedasticity, and multicollinearity tests. The results of the regression analysis showed that the independent variables (age, gender, education, and income) had no significant effect $(p=0.346)$ simultaneously on the consumer empowerment with an F-value of 1.153 and Adjusted R2 of 0.015 . This means that only $1.5 \%$ of consumer empowerment is influenced by the variables studied. The remaining 98.5\% was influenced by other variables that were not studied (Table 7).

Table 7: The results of the factors that affect the consumer empowerment index

\begin{tabular}{lrrr}
\hline \multirow{2}{*}{ Independent variable } & \multicolumn{2}{c}{ Consumer empowerment } & \multirow{2}{*}{$p$} \\
\cline { 2 - 3 } Constant & Unstandardized B & Standardized B & 0.000 \\
Age (years) & 78.371 & -0.269 & $0.091^{*}$ \\
Gender (0: female; 1: male) & -0.417 & -0.083 & 0.659 \\
Job status & -2.036 & 0.009 & 0.971 \\
Length of education (years) & 0.185 & -0.047 & 0.803 \\
Income (rupiah / month) & -1.040 & -0.122 & 0.393 \\
\hline F & $-5.006 \mathrm{E}-7$ & \\
Adj. $\mathrm{R}^{2}$ & 1.153 & \\
$p$ & 0.015 & \\
\hline
\end{tabular}


INDEPENDENT JOURNAL OF MANAGEMENT \& PRODUCTION (IJM\&P)

http://www.ijmp.jor.br

v. 12, n. 5, July-August 2021

ISSN: 2236-269X

DOI: 10.14807/ijmp.v12i5.1443

Partially, 1 of the 5 variables tested had a significant effect on the consumer empowerment index, namely age. Age had a significant negative effect $(\beta=-0.269 ; p=0.091)$ on the consumer empowerment index, meaning that the higher the age of the respondent, the lower the consumer empowerment index (Table 7). The regression equation to determine the effect on the consumer empowerment index in educational institutions is as follows:

$$
\mathrm{Y}=78.371-0.417 \mathrm{X} 1-2.036 \mathrm{X} 2+0.185 \mathrm{X} 3-1.040 \mathrm{X} 4-5.006 \mathrm{E}-7 \mathrm{X} 5+\varepsilon
$$

\section{DISCUSSION}

The results of the research on consumer empowerment index in educational institutions are in the capable category (54.34). When compared with previous research conducted by Simanjuntak and Yuliati (2014), the index of consumer empowerment in the food sector is in the understanding category (26.57). In contrast to research conducted by Simanjuntak (2019), the index of consumer empowerment in online purchases is in the capable category (49.7), while research conducted by Saniya (2017) shows the consumer empowerment index in the field of public transportation is in the capable category (44.56). This means that the consumer empowerment index in educational institutions is higher than the consumer empowerment index in the food sector, online purchases, or in the field of public transportation.

Based on the results of the study, the average respondent was only in the capable category and was considered less empowered. This means that respondents are only able to use their rights and obligations as a consumer to determine the best choice, including choosing educational institutions that are right for themselves, not reaching the stage of fighting for their rights. This can be because the highest percentage of respondent complaint behavior is in the less category (73.1\%), thus making the consumer empowerment index low. All CEI categories are dominated by the female gender. Several categories of CEI are dominated by unemployment status. This is arguably because the majority of respondents are housewives so that the proportion of the two characteristics is not balanced.

Respondents with the lowest average consumer empowerment index score are respondents who are in the old age category (51-65 years), are male, highly educated (>12 years), employed, have an income of $>$ Rp3,204,551/month. Respondents who have these characteristics can be the main target in consumer education. The lowest average consumer empowerment index score is the complaint behavior dimension (41.99). This is due to the low percentage of behavior filing a complaint when experiencing disappointment.

Respondents’ skills in conducting information searches before choosing an educational institution are in the inactive category (51.92\%). The information-seeking dimension has the 
DOI: 10.14807/ijmp.v12i5.1443

second-lowest average index (60.26) after the complaint behavior dimension. This can be one of the causes for the low average score of the consumer empowerment index in educational institutions.

The view on Empowerment emphasizes the need for the rule of law and trust in the purchasing environment (SHIBLY, 2009). Research shows that the dimension of knowledge about consumer protection laws and institutions has an average index of 71.15, and 9 out of 10 respondents know consumer protection institutions. The results showed that the dimension of purchasing behavior had an average index of 72.44, and the average respondent always paid attention to accreditation before choosing an educational institution.

Broad information and ease of communication can form a communication network as a means of exchanging information and evaluating consumers on a product or service (Shibly, 2009). This factor is very necessary when choosing an educational institution. The results show that the dimension of the tendency to talk has an average index of 66.35, and on average, the respondents share their bad experiences with others. The complaint behavior dimension is the dimension with the lowest average index (41.99) compared to the other four dimensions. This is because respondents are in the poor category (73.1\%) in making complaints and show a lack of consumer awareness to complain when they get a loss or experience disappointment.

\subsection{The Effect of Demographic Characteristics on Consumer Empowerment}

The results show that the overall hypothesis is not supported in the demographic characteristics variable but only supported Hypothesis 1a, namely, age has a significant effect on consumer empowerment in educational institutions. Yuliati et al. (2012) classify ages as early adulthood (19-24 years), young adulthood (25-35 years), middle adulthood (36-50 years), older adulthood (51-65 years), and elderly (>65 years old). The average age of the respondents was 43.23 years, which is included in the middle-aged category. This is indicated by the largest percentage of respondents in the middle-aged category. According to Lyon et al. (2002)The older the consumer, the more they need empowerment.

The results show that respondents in the early adult category (19-25 years) are more empowered than other adult age groups. The category of early adulthood has the largest average on the dimensions of information seeking, purchasing behavior, and complaint behavior. The regression test results show that age has a significant negative effect on consumer empowerment. The results of the study accept Hypothesis 1a, namely, age has a significant negative effect on consumer empowerment. This is in line with research conducted by Nardo et al. (2011) and Lyon et al. (2002), which states that empowerment is influenced by age. 
DOI: 10.14807/ijmp.v12i5.1443

Based on the research results, female respondents are more empowered than male respondents. Female respondents have the largest average dimension in all dimensions of consumer empowerment. This is in line with research conducted by Simanjuntak and Yuliati (2016), which states that female consumers are more empowered than male consumers. The results of the study do not support Hypothesis 1b, namely, gender has a significant effect on consumer empowerment and is not in line with other studies which state that male respondents are more empowered than female respondents (Simanjuntak, 2019; Midha, 2012).

\subsection{The Effect of Social Characteristics With Consumer Empowerment}

The results show that the overall hypothesis is not supported by social characteristics variables. The average length of education of the respondents is 13.17 years or equivalent to completing high school. In this study, the average consumer empowerment index with middle education is more empowered than the respondents with high education. This is not in line with other research, which states that empowerment is influenced by the length of education (Simanjuntak, 2019; Ghlipour, 2010; Nardo et al., 2011; Rahman \& Naoroze, 2007; Simanjuntak \& Yuliati, 2015;).

The largest proportion of respondents' employment status is employed. Based on the research results, the average index of consumer empowerment who does not work is more empowered than the respondents who work. This is presumably because respondents who do not work have enough time to search for information, study laws and consumer protection agencies, and complain behavior. Unemployed consumers have the highest rates on the dimensions of information seeking, knowledge of consumer protection laws and institutions, purchasing behavior, and complaint behavior. This is not in line with research conducted by Nardo et al. (2011) and Simanjuntak (2019) which state that consumers who are not actively working are less empowered than those who work.

\subsection{The Effect of Economic Characteristics With Consumer Empowerment}

The results show that the overall hypothesis 3 on the economic characteristics is not supported, saying that income has a significant effect on consumer empowerment in educational institutions. The average income of the respondents was Rp4,629,807.69. Respondents with income $\leq \mathrm{Rp} 3,204,551$ are more empowered than respondents whose income is $>\mathrm{Rp} 3,204,551$. Respondents with income $\leq \mathrm{Rp} 3,204,551$ have the largest average in the dimensions of information seeking, purchasing behavior, and complaint behavior. This is in 
DOI: 10.14807/ijmp.v12i5.1443

line with the research of Nardo et al. (2011), which states that income has an inverse relationship with empowerment.

\section{CONCLUSION AND RECOMMENDATION}

\subsection{Conclusion}

The results show that the respondents in this study have an average age of 43.23 years, are female, had education above high school/equivalent, do not work, and an average income is Rp1,140,785 per capita per month. The level of consumer empowerment in educational institutions is still low because the average consumer empowerment index for educational institutions is 54.34, which is included in the capable category. Multiple linear regression test shows that age affects the consumer empowerment index.

\subsection{Recommendation}

Based on the research results, the consumer empowerment in educational institutions is still low, especially in the behavior of complaints. It is necessary to re-test the instrument with different variables and targets to increase the validity of future studies, and it is also suggested that we can find out more about the reasons consumers make or do not make complaints. To form smart and empowered consumers, it is necessary to recognize consumer rights and obligations through direct or indirect education via the internet or social media as a source of information that is widely accessed by consumers so as to encourage consumers to use their rights as consumers and complain when they are harmed or experience disappointment.

Also, the scope and instruments of this research are limited, only to formal educational institutions, so it is necessary to develop the scope and develop existing instruments. Incorporating other variables that might have an impact on consumer empowerment is expected in future studies.

\section{REFERENCES}

Chandrasekhar, B. V. N. G. (2012). Consumer buying behaviour and brand loyalty in rural markets. Journal of Business and Management, 4(2), 50-67. DOI: 10.9790/487X-0325067

Chaudry, I. S., \& Nosheen, F. (2009). The determinants of women empowerment in Southern Punjab (Pakistan): An empirical analysis. European Journal of Social Science, 10(2).

Collard, S., De La Mata, A., Frade, C., Kempson, E., Leskinen, J., Lopes, C., Moore, N., Nicolini, G., Noel, D., Raijas, A., \& Selosse, C. (2006). Consumer financial capability: Empowering European consumers. European Credit Research Institute. Available: http://www.ecri.eu/new/system/files/Fincap_Workshop_I_papers.pdf. 
Cutler, T. J., \& Nye, D. A. (2000). Anything but 'empowerment'? Smokers, tar and nicotine data and cigarette design. Health, Risk, and Society, 2(1), 69-81. DOI:

10.1080/136985700111468

Damayanti, S. N. (2017). Pengaruh karakteristik individu, gaya hidup, dan motivasi terhadap keberdayaan konsumen di bidang perumahan [The influence of individual characteristics, lifestyle, and motivation on consumer empowerment in the housing sector]. Thesis. Bogor: Bogor Agricultural University. Available:

https://repository.ipb.ac.id/handle/123456789/88269

Gholipour, A., Rahimian, A., Mirzamani, A., \& Zehtabi, M. (2010). Impact model of women's empowerment. International Business Research, 3(1), 57-65. DOI:

10.5539/ibr.v3n1p57

Handoyo, I. G. S. R., \& Setiawan, P. Y. (2015). Pengaruh karakteristik demografi dan ketidakpuasan terhadap perilaku mengeluh konsumen pada bengkel service sepeda motor yamaha Diponegoro Denpasar Bali [The influence of demographic characteristics and dissatisfaction on the behavior of consumers complaining on service workshop Yamaha motorcycle Diponegoro Denpasar Bali]. E-Jurnal Manajemen Unud, 4(10), 3317-3345. Available: https://ojs.unud.ac.id/index.php/Manajemen/article/view/14593

Heung, V. C. S., \& Lam, T. (2003). Customer complaint behavior toward hotel restaurant service. International Journal of Contemporary Hospitality Management, 15(5), 283289. DOI: $10.1108 / 09596110310482209$

Hunter, G. L., Harrison, T., \& Waite, K. (2006). The dimensions of consumer empowerment. In Enhancing Knowledge Development in Marketing, AMA Educator's Proceedings, 17, 207-208. Available: https://www.ama.org/wp-content/uploads/2019/02/2006-ama-summerproceedings.pdf

Ishak, S., \& Zabil, N. F. (2012). Impact of consumer awareness and knowledge ton consumer effective behavior. Journal of Asian Social Science, 8(13), 263-296. DOI:

10.5539/ass.v8n13p108

Killackey-Jones, B, Lyle, R, Evers, W, \& Tappe, M. (2004). An effective one-hour consumer-education program on knowledge, attitude, and behaviour toward functional foods. Ideas at Work, 42(1). Available: https://www.joe.org/joe/2004february/iw2.php

Lyon, P., Kinney, D., \& Colquhoun, A. (2002). Experience, change and vulnerability: consumer education for older people revisited. International Journal of Consumer Studies, 26(2), 178-187. DOI: 10.1046/j.1470-6431.2002.00240.x

Midha, V. (2012). Impact of consumer empowerment on online trust: An examination across genders. Decision Support System, 54(1), 198-205. DOI: 10.1016/j.dss.2012.05.005

Nardo, M., Loi, M., \& Rosati, R., Manca, A. (2011). The consumer empowerment index: A measure of skills, awareness and engagement of Europeun Consumers. JRC Scientific and Technical Reports. Luxembourg: Publications Office of the European Union 24791 EN2011.

National Commission On Human Rights. (2014). Laporan Data Tahunan [Annual Data Report]. National Commission on Human Rights. Available:

https://www.komnasham.go.id/index.php/laporan/2017/03/21/25/laporan-tahunan-komnasham-tahun-2014-indonesia.html

National Commission On Human Rights. (2015). Laporan Data Pengaduan [Complaint Data Report]. National Commission on Human Rights Available: 
https://www.komnasham.go.id/index.php/data-pengaduan/2016/01/01/12/laporan-datapengaduan-tahun-2015.html

National Commission On Human Rights. (2016). Laporan Tahunan Bagian Dukungan Pelayanan Pengaduan Tahun 2016 [2016 Annual Report of the Complaint Service Support Section]. National Commission on Human Rights. Available: https://www.komnasham.go.id/index.php/data-pengaduan/2017/12/06/28/laporan-tahunanbagian-dukungan-pelayanan-pengaduan-tahun-2016.html

Ngai, E. W. T., Heung, V. C. S., Wong, Y. H., \& Chan, F. K. Y. (2007). Consumer complaint behaviour of Asians and non-Asians about hotel services an empirical analysis. Europeun Journal of Marketing, 41(11). DOI: 10.1108/03090560710821224

Rahman, M. H., \& Naoroze, K. (2007). Women empowerment through participation in aquaculture: experience of a large scale technology demonstration project in Bangladesh. Journal of Social Science, 3(4), 164-171. DOI: 10.3844/jssp.2007.164.171

Saniya, R. U. (2017). Pengaruh karakteristik demografi, sosial, dan ekonomi serta akses media pendidikan konsumen terhadap keberdayaan konsumen di bidang transportasi umum [The effect of demographic, social and economic characteristics, and access to consumer education media on consumer empowerment in the field of public transportation]. Thesis. Bogor: Bogor Agricultural University. Available: http://repository.ipb.ac.id/handle/123456789/89759

Shibly, H. A. (2009). A characterisation of consumer empowerment drawn from three views of power. ABAC Journal, 29(3), 65-74. Available:

http://www.abacjournal.au.edu/2009/sep09/05_Characterisation.pdf

Simanjuntak, M., \& Mubarokah, U. (2021). Investigating how consumer education and lifestyle influence the consumer empowerment: case in rural and urban areas, indonesia. Independent Journal of Management \& Production. Forthcoming.

Simanjuntak, M. (2014). Tingkat keberdayaan dan strategi pemberdayaan konsumen [Level of empowerment and consumer empowerment]. Dissertation. Bogor: Bogor Agricultural University. Available: https://repository.ipb.ac.id/handle/123456789/70073

Simanjuntak, M. (2015). Consumer empowerment index among undergraduate students of Bogor Agricultural University, Indonesia. Asian Journal of Business and Management, 3(3), 183-191.

Simanjuntak, M. (2019). Generation Y's complaint behavior toward online shopping. Independent Journal of Management \& Production, 10(1), 101-116.

http://dx.doi.org/10.14807/ijmp.v10i1.839

Simanjuntak, M., \& Musyifah, I. (2016). Online shopping behavior on Generation Y in Indonesia. Global Business Finance Review, 21(1), 33-45.

Simanjuntak, M., \& Putri, R.R.E. (2020). How empowered is the consumer in telecommunications sector: the role of socio-demographic and lifestyle? Indonesian Management Journal, forthcoming.

Simanjuntak, M., \& Putri, S.A. (2018). Consumer empowerment index of electronic product buying. Independent Journal of Management \& Production, 9(4), 1165-1183.

http://www.ijmp.jor.br/index.php/ijmp/article/view/814

Simanjuntak, M., \& Yuja, S. (2021). Understanding The Consumer Empowerment In Health Service. Independent Journal of Management \& Production. forthcoming. 
Simanjuntak, M., \& Yuliati, L. N. (2016). Indeks Keberdayaan Konsumen di 13 Provinsi di Indonesia 2016 [Consumer Empowerment Index in 13 Provinces in Indonesia 2016] (Research Report). Bogor Agricultural University.

Simanjuntak, M., Amanah, S., Puspitawati, H., \& Asngari, P. (2014). Modelling consumer empowerment level. Economic Journal of Emerging Markets, 5(2), 109-119. DOI: 10.20885/ejem.vol5.iss2.art4

Simanjuntak, M., Amanah, S., Puspitawati, H., \& Asngari, P. S. (2013). Modelling consumer empowerment level. Economic Journal of Emerging Markets, 5(2), 109.119. DOI: 10.20885/ejem.vol5.iss2.art4.

Simanjuntak, M., Amanah, S., Puspitawati, H., \& Asngari, P. S. (2014). Consumer empowerment profile in rural and urban area. Asean Marketing Journal, 15(1), 38-49. DOI: 10.21002/amj.v6i1.3611.

Simanjuntak, M., Amanah, S., Puspitawati, H., \& Asngari, P. S. (2014). Study of consumer education in Bogor, Indonesia. Asian Journal of Business and Management, 2(5), 481-490.

Simanjuntak, M., Hamimi, U.K. (2019). Complaint handling and Word-of-Mouth (WOM) communication. Journal of Family \& Consumer Science, 12(1), 75-86.

https://doi.org/10.24156/jikk.2019.12.1.75

Simanjuntak, M., Utami, F. S., \& Johan I. R. (2015). Vulnerability of consumers and purchasing behavior of packaging food products. Jurnal Ilmu Keluarga \& Konsumen, 8(3), 193-273. DOI: 10.24156/jCEI.2015.8.3.193.

Sofyan, A. I. (2017). Pengaruh karakteristik sosio-demografi, gaya hidup dan persepsi resiko terhadap keberdayaan konsumen di bidang asuransi kesehatan. Thesis. Bogor: Bogor Agricultural University. Available:

https://repository.ipb.ac.id/handle/123456789/88248

Sudaryatmo. (1996). Masalah perlindungan konsumen di Indonesia. Bandung: PT. Citra Aditya Bakti.

Sumiyati, S., \& Fatmasari, R. (2006). Consumer foundation role in providing protection for consumers. Jurnal Pena Wiyata: Jurnal Pendidikan dan Humaniora, 5(9). DOI: 10.24156/jikk.2012.5.2.166

Tayde, V., \& Chole, R. (2010). Empowerment appraisal of rural women in Marathwada region of Maharashtra state. Indian Res. J. Ext. Edu, 10(1), 33-36. Available: http://www.seea.org.in/vol10-1-2010/08.pdf

Tuty, D. W. N., Widiyanti, E., \& Utami, B. W. (2017). Korelasi faktor pembentuk persepsi dengan persepsi konsumen terhadap media pemasaran online (www.goodplant.co.id) [Correlation of perception forming factors with consumer perceptions of online marketing media (www.goodplant.co.id)]. Journal of Sustainable Agriculture, 32(2), 108-115. DOI: 10.20961/carakatani.v32i2.14996

Wandani, D., \& Simanjuntak, M. (2019). Personality, motivation, and behavior of complaints based on ethnicity. Journal of Family \& Consumer Science, 12(3), 236-247. https://doi.org/10.24156/jikk.2019.12.3.236

Yuliati, L. N., Retnaningsih, \& Aprilia, D. (2012). Pengaruh kelompok acuan terhadap kesadaran dan konsumsi beras merah (Oryza nivara) [The influence of reference groups on awareness and consumption of brown rice (Oryza nivara)]. Jurnal Ilmu Keluarga dan Konsumen, 5(2), 166-174. DOI: 10.24156/jikk.2012.5.2.166 